\title{
ISIS: PAST, PRESENT, AND FUTURE
}

\author{
According to Abu musab al-Zarqawi:
}

"We will fight in the cause of God until His Shari' ah prevails. The first step is to expel the enemy and establish the state of Islam. We would then go forth to reconquer the Muslim lands and restore them to the Muslim nation... I swear by God that even if the Americans had not invaded our lands together with the Jews, the Muslims would still be required not to refrain from jihad but go forth and seek the enemy until only God Almighty's Shari'ah prevailed everywhere in the world... Our political project is to expel this marauding enemy. This is the first step. Afterwards our goal is to establish God's Shari' ah all over the globe... We will not be revealing a secret when we say that we seek to establish Islamic justice in the entire world and crush the injustice of disbelief and the iniquity of other religions" (Hashim, 2014: 70).

ISIS, the Islamic State of Iraq and Syria (al-Dawla al-Islamiya fi al-Iraq wa al-sham), its roots lie in organization of monotheism and Jihad (Jama'at al-Tawhid wal-jihad) was established in 1999 in Jordan by Abu Musab al-Zarqawi (born in 1966 under the birth name of Ahmad Fadhil Nazzal al-Khalayla) who travelled to Afghanistan at the end of the 1980s to assist the insurgents in their war against NATO troops (see: Raphaeli, 2005), and after the war returned to his land of nativity (Abbas, 2014: 1-2). Between the years 1994-1999, al-Zarqawi and his mentor, Abu Mohamed al-Maqdisi, were imprisoned in a penitentiary in Jordan (Bunzel, 2015: 13). In 2003, Zarqawi transferred his activism to Iraq, in response to the invasion by the United-States, and by 2004 he had joined Al-Qaeda (see Fishman, 2014). After Zarqawi's assassination in 2006, Abu Ayyub al-Masri inherited his position and changed the name of the organization to the Islamic State of Iraq (ISI), and which sought control over Iraq's territory. After the assassination of al-Masri in 2010 (see: Roggio, 2010), Abu Bakr al-Baghdadi began to take command over the organization, and in 2012 the organization began to take part in the civil war in Syria, during which time he again changed the name of the organization to the Islamic State of Iraq and the Levant (ISIL), or, conversely, to the Islamic State of Iraq and Syria (ISIS). In 2014, Abu Bakr al-Baghdadi once again changed the name of the organization to the Islamic State (IS), and became the self-proclaimed Caliph of the Islamic State (Blumenau, 2015).

\section{THE ISIS IDEOLOGY}

Al-Qaradawi defined the Islamic State in terms that contradict a religious state, when he said:

"The Islamic state which Islam brought, and as is known in the history of the Muslims, is a civil state (dawlah madaniyah); political power is set up in it on the basis of the 
pledge of allegiance (al-bay'ah) and choice (al-ikhtiyar) and al-shura (consultation), and the ruler in it is the agent (wakil) of the ummah or its employee (ajir). It is the right of the ummah - represented in the people of authority (ahl al-hal wa al-'aqd) among them - take him to account; to supervise or censure him; to command him and prohibit him; and to rectify his course if he deviates, and if not - to remove him. It is among the rights of every Muslim, rather of every national citizen (muwatin), to disavow him if he sees him sinning and engaging in reprehensible actions, or failing to enjoin what is just. It is incumbent on the people to declare revolution (al-thawrah) against him if they see that he is an infidel (kafir) according to the criteria of Allah. As for the religious 'theocratic' state which the west knew in the Middle Ages, and which was ruled by the men of religion who retained their rule by the necks - and conscience - of people in the name of the 'divine right' ... it is rejected by Islam"' (Belkeziz, 2009: 127).

While there is unanimity among all radical groups regarding the creation of an Islamic state by acts of terrorism and Jihad, and where Sharia-law would prevail therein, there is a big difference between al-Qaeda and ISIS in terms of their priorities. Al-Qaeda stresses the need to implement Jihad on a world-wide scale before declaring the establishment of the Islamic State, but ISIS demands the establishment of an Islamic State without delay. ISIS sees the fulfillment of this one demand as an "unbreachable" condition (sine qua non), without which it will be impossible to apply the Sharia-law (see: Baghdadi's approach, Napoleon, 2015: 158-159). ISIS's approach is that the establishment of an Islamic State is considered of such urgency and vital necessity that it precludes fighting, in their view, with the distant enemy (i.e. the West) until a later and more opportune time. The Islamic State's magazine, Dabiq, published a reliable oral account (hadith $S a h \bar{h} h$ ) attributed unto the prophet Muhammad where it clearly points out the objectives of the organization: First, Saudi-Arabia; afterwards, Iran; and lastly, Rome (the West):

"You shall invade the Arabian Peninsula, and Allah will deliver it into your hands, and
then you shall invade Persia, and Allah will deliver it into your hands, and then you
shall invade Rome, and Allah will deliver it into your hands; and then you shall fight
against Satan, and Allah will deliver him into your hands".

Incidentally, it is also important to mention that ISIS requires unequivocally to fight unto the death Jihadist organizations which do not swear allegiance to the Caliphate (Carmon, Joshua, Arie, 2014). ISIS is a radical Salafi organization that draws its radical extreme philosophy (like many radical Islamic organizations) from the ideology of the Egyptian intellectual, Sayyid Qutb (1906-1966), who is considered by many western analysists as the father of all contemporary radical Islamic groups (Sivan, 1989: 1). The underlying principles of Sayyid Qutb's philosophy present such methodologies as jahiliyya (ignorance), the Islamic State, Jihad and Hakimiyyah (God's sovereignty) (Knapp, 2002: 37-38, 40-41), which have been interpreted in different ways by many groups. These groups (such as A1-Qaeda, ISIS, etc.) have given to their writings an independent interpretation, namely, that it is necessary to embark on a physical struggle against all infidels. The ideology of extremist organizations is based on the concept that it is necessary to restore Islam unto its untainted and pristine roots, just as it was during Muhammad's time, and during the three succeeding generations after the Prophet Muhammad, beginning with the first decade of the $7^{\text {th }}$ century CE. The harsh ideological crisis experienced by the Islamic world during its fall from its preeminence in the 
past several hundred years has led Muslim thinkers into trying to find solutions that will rescue the Islamic world from its deep ideological crisis. Rashid Rida (1865-1935), who developed a theory that paved the way for many extremist organizations (see Sirriyeh, 2000), advocated that in order to be saved from the dire situation there is a need to return to the roots of Islamist violence, just as it was at the advent of Islam (Barack, 2012: 25, 28-33). In addition, ISIS bases its ideology upon the Qur'an, while Abu Bakr al-Siddiq, the successor of the Prophet Muhammad, when asked by his men why he doesn't go-forth and liberate Jerusalem (see: Ibrahim, 2014), replied unto them that the "near enemy" (the Muslim infidels) was more important to subdue than the "distant enemy" (the West) (ISIS: Portrait, 2014: 2-3, 36).

Self-professed Caliph, Abu Bakr al-Baghdadi, stated in July 2014:

"My dear [Muslim] community: As we did not lie against God when we announced the Islamic State, so we do not lie against God when we say that it will persist... It will persist upon its creed ('aqida) and its path (manhaj), and it has not, nor will it ever, substitute or abandon these" (Bunzel, 2015: 4).

After Baghdadi announced in 2014 the founding of the Islamic State, and declared himself as its Caliph (see: Blumenau, 2015), the Western world was in turmoil. On the one hand, many in the West saw in Baghdadi's organization a real threat to the West, while, on the other, there were not a few who argued that ISIS is just another violent group in the Middle-East. However, it is necessary to take into account one very important fact, how that, since the Second World War, there has never been an armed group who took control over a territory as large as that controlled by ISIS today, a matter that should switch on a "red light" to all leaders of the free world. At a time when not a few people in the Western world argue that ISIS is only a neighborhood bully that can never endanger the West in any substantial manner, Baghdadi's organization is developing and prospering, while presenting an innovative model of nation-building (see: Perthes, 2014) which is based, in one aspect, on the old Islamic legacy as it existed during the advent of Islam, while, in a different aspect, its model is based on globalization on modern technology. Another thing that should be taken into account is the fact that many in the Sunni world see ISIS and its leader Baghdadi as the Salafi State that has resurrected through the severe distress into which the Muslim world had fallen. This new awakening and revival, however, must be attributed unto Zarqawi. At the center of Baghdadi's thought, he presents himself as a man of equals amongst his following, while the message that he delivers to his protégés is that if they should ever see him err, they are to make it known unto him so that he can correct his ways. However, if they are to see that he is correct in his way, they are to assist him at whatever cost it might take. This matter distinguishes Baghdadi and highlights his charismatic leadership, insofar that it attracts many Muslims worldwide into joining his organization. Moreover, Baghdadi presents his organization as the legitimate contender for the establishment of the Islamic state, whose primary aim is to fight against Muslim rulers who have veered from the straight path (see: Sayyid Qutb's similar approach, Cottee, 2010: 336-337), as well as to wage war against Western powers who have corrupted every good aspect that could be found in the Muslim society. In his call to Muslim believers throughout the world, Baghdadi demands of his followers to immigrate to the Islamic state, saying that it is the obliga- 
tion of every Muslim to join Dar al-Islam (the house of Islam). When explaining the prerequisite for joining Dar al-Islam, he asks of Muslim believers to return to their pure Islamic roots, just as they were during the time of the Prophet Muhammad. The main goal of al-Baghdadi is to establish an Islamic state in Iraq and Syria in order to pass-on to Muslims the legacy bequeathed to them by the Prophet Muhammad, which is adamantly opposed to modernization and everything that it represents (Napoleoni, 2015: 158-159). "The ideology of the Islamic State is that of Salafist-Jihadism. It is important to remember that for them there is no distinction between religion and state. All decisions are based on a hard line interpretation of Sharia (Islamic law), which is brutally enforced in the areas controlled by the Islamic State. The ideology is almost exactly the same as that of other groups such as A1-Qaeda and the Taliban. It differs in its approach to the proper timing and the conditions necessary to establish a caliphate. Groups such as Jabhat Al-Nusra (Al-Qaeda's official affiliate in the Syrian Civil War) believe that although the long term goal is to establish an Islamic caliphate, the time is not yet right for such a move" (The Islamic State, 2015: 13).

For many Muslims across the globe, the establishment of an Islamic State by ISIS is a lofty and sublime ambition which carries with it much nostalgia for Islam's glorious past, while ISIS's propaganda revolves around the Islamic Caliphate as it existed during the Prophet's time, and during the time of the four caliphs who succeeded him after his death in $632 \mathrm{CE}$, until $661 \mathrm{CE}$, a period considered the Golden-Age of Islam (Zirvi, 2008: 13), which epitomizes Islam in all its splendor and purity. This period is called by many Islamists, Salafism, behind which concept is the call to return to Islamic roots, with what is related to a physical struggle as it existed at the beginning of Islam. In an effort to achieve this goal, the organization began to carry-out beheadings, stoning, crucifixions and enslavement, which, on the one hand, served as a deterrent against those who would prevent the organization from developing. On the other hand, the organization declared that these actions were intended for those who did not want to change their religion to Islam, what some see as an excuse to conceal and disguise the personal and organizational interests of the ISIS leaders. In order to explain why many Muslims around the world are interested in joining ISIS, the historian Fred Donner of Chicago University argues that in the Muslim world there exists a unique kind of mystical belief which appeals to the emotions of all Muslims in the world, and which is most-skillful at igniting a yearning for pure Islam, just as it existed in the $7^{\text {th }}$ century CE. This mystical belief determines that, in the event that an Islamic caliphate is established, many Muslims will become enlightened and will be enticed to bring to fruition this dream (Wood, 2014: 15). After Zarqawi's assassination in 2006 by American military forces (see: Finer, Knickmeyer, 2006), and when attempts to establish an Islamic State had failed, Abu Ayyub al-Masri declared: "The mujahidin have reached the end of a stage of jihad and the start of a new one, in which we lay the first cornerstone of the Islamic Caliphate project and revive the glory of religion" (Hashim, 2014: 72). However, jihadists had not the resources, nor the leadership, which could have led to the establishment of an Islamic state. On the other hand, the great frustration felt after the death of Zarqawi, jihadists brought about an increased intensity in their attacks of terror. That is to say, the lack of success in establishing an Islamic state, and the deep stalemate led to increased motivation which led to a greater awakening among the jihadists. The allocation of 
forces against ISI in Iraq (see: Fishman, 2008) in the course of 2008 highlighted the fact that the organization failed to establish an Islamic state, while government stability in Iraq only strengthened this fact. At the beginning of 2009, United States forces began to withdraw from the cities throughout Iraq (Katzman, 2009: 6), with the aim of gradually transferring control of the state to the local government. Towards the end of 2009, ISIS began to improve its position by a number of violent acts that succeeded in inflicting damage to government infrastructure, and killing hundreds of citizens, a thing that severely set-back the plans of the Americans to stabilize the government in Iraq. In April of 2010, ISIS suffered a heavy blow when the leader of that organization, Abu Ayyub al-Masri, along with Abu Umar Abdullah al-Rashid al-Baghdadi, were killed by United States armed forces (Nance, 2015: 55-56), an operation that underscored the fact that $80 \%$ of ISI's leadership had been either killed or captured by the US military. Abu Bakr al-Baghdadi filled the shoes of al-Masri, and forthwith the organization began to change course, going from one extreme to the other, and which highlighted the charisma of the new leader. Baghdadi had learned from past mistakes (see: Eckman, 2014), and began to rebuild the organization in a centralized hierarchical manner with which he would have more flexibility and so that it would immediately meet the ever-changing needs and requirements of the organization.

The breakthrough was made possible in March 2013 with the outbreak of the civil uprising in Syria. Al-Baghdadi immediately took notice of a historic opportunity at hand. He realized at once that Assad's regime in Syria was dominated by a secular infidel Alaoo'it group that did not belong to Islam, and which tries to harm Muslims. Likewise, Baghdadi's greatness is expressed in the fact that he immediately understood that there was a vast area in Syria wherein there existed a vacuum, and this afforded him a golden opportunity in which his troops were able to hone their skills in a war against an organized army. Upon entering the war, he changed the name of his organization to the Islamic State of Iraq and Syria (ISIS) (Hashim, 2014: 72-73, 77).

\title{
THE RELATIONS BETWEEN ISIS AND AL-QAEDA
}

\begin{abstract}
"My testimony today will focus on comparing Al-Qaeda and the Islamic State. I argue that Al-Qaeda and its affiliates remain a threat to the U.S. homeland, while the Islamic State's danger is more to the stability of the Middle East and U.S. interests overseas. Much of their rivalry involves a competition for affiliates, with both trying to spread their model and in Al-Qaeda's case to ensure its operational relevance. For now the Islamic State's focus is primarily on Iraq and Syria and to a lesser degree on other states in the Muslim world, particularly Libya. In the United States and in Europe it may inspire "lone wolves," but it is not directing its resources to attack in these areas, and security services are prepared for the threat. Al-Qaeda is weaker and less dynamic than the Islamic State, but the former remains more focused on attacking the United States and its Western allies" (Byman, 2015)
\end{abstract}

Zarqawi officially joined the group A1-Qaeda in October of 2004, under the leadership of Osama bin Laden (see: Kahati, 2006). The group was then called Tanzim Qaidat al-Jihad fi Bilad al-Rafidayn, or Al-Qaeda in Iraq (AQI). Zarqawi's enlistment was meant, on one hand, to strengthen al-Qaeda's ranks against the United-States, while, of 
secondary importance, Zarqawi's prestige added a new element to the ranks of the organization. The organization started to highlight a number of principles in order to get a better grip on Muslims, by making use of expressions such as: Its stance that adamantly opposed polytheism, and promoted monotheism (tawhid), whereas anyone who didn't walk in the ways of God (according to their understanding) was considered an apostate; the concept of takfir (excommunication) gave to them the legitimacy to implement their goals by pursing a holy war. Jihad became the primary tool for implementing their teaching, insofar that they declared that jihad was an obligation of all Muslims in the world against infidels. The leaders of Al-Qaeda, together with Zarqawi, were in full-agreement in all which concerns the group's ideology and objectives, but in the course of their opposition towards the United-States in Iraq, a division began to surface about how best to prosecute the war. Zarqawi was a great fan of massive attacks against heavily-populated areas, for which cause he was coined the epithet, "Sheikh of the slaughterers" (see: Raphaeli, 2005). Disputes began to gain momentum when his spiritual mentor, Abu Muhammad al-Maqdisi (who was more moderate and considered one of the principal thinkers representing the Salafist faction in Jordan), began to criticize on his activity (see: Wagemakers, 2014). In 2005, al-Maqdisi wrote to Zarqawi, asking him to desist from harming citizens, churches and Shi'ites, while later al-Maqdisi claimed that the main enemies were the American occupiers. Zarqawi replied that the advice which al-Maqdisi had given to him wasn't fair, while he presented the Shi'ites as being ostracized apostates to the faith, and determined that the war against the Shi'ites was more important than fighting against non-Muslims, and accused the Shi'ah as an evil cult responsible for the ethnic conflict in Islam. Ayman al-Zawahiri, Osama bin Laden's deputy, wrote a letter to Zarqawi, expressing his complete approval of the objectives and the operational method of jihad in Iraq, although he had his reservations about the approach used by him in achieving his objectives. Al-Zawahiri argued that, while the Shi'ites were traitors, he still opposed any violent action against them. According to al-Zawahiri, Zarqawi's acts of beheading were not necessary, seeing that they turn away many from Islam and cause unprecedented damage to the organization's set goals. After Zarqawi's killing by US forces on June 7, 2006, Abu Hamza al-Muhajir (Abu Ayyub al-Masri) became the most senior figure of AQI in Iraq.

In 2010, al-Masri was killed by US forces, and his place was taken over by Baghdadi. In 2012, several attempts were made to unite the Jabhat al-Nusra organization, which was under the command of Abu Muhammad al-Jawlani, with Baghdadi's organization in its war against Syria. However, at the end of such endeavors in 2013, Ayman al-Zawahiri (Al-Qaeda's leader) determined that he was vehemently opposed to such a union, and declared that the Jabhat al-Nusra organization would fight in Syria, and that ISIS would fight in Iraq. Baghdadi announced that he was opposed to Zawahiri's directive, and continued in his attempts to unite the two factions. In October of 2013, Zawahiri ordered the dismantling of ISIS and the mobilization of the Jabhat al-Nusra organization in the fight over Syria. In February of 2014, ISIS's relationship with A1-Qaeda ended with Zawahiri's announcement that ties between the two groups had been severed (Hashim, 2014: 71-72, 77-78).

In 1999, Zarqawi founded Jamaat al-Tawhid wa-l-Jihad (JTWJ) in Jordan, while Bin Laden founded A1-Qaeda during the 1980s in Afghanistan. Nevertheless, the two 
leaders had completely different approaches, stemming from the different backgrounds and ambitions of these two leaders ${ }^{1}$. While Bin Laden and his leadership came from middle to upper-class backgrounds, who earned their education in universities, Al-Zarqawi and his leadership came from the lower-class who were uneducated. The radical views of Zarqawi stemmed from his strong belief in takfir (where they accused Muslims of heresy who departed from the path of equity, giving them, therefore, the legitimacy to wage a holy war against them). When Zarqawi first met Bin Laden in Afghanistan in 1999, he had no great affection for him. Throughout the 1980s, Bin Laden enjoyed unparalleled popularity amongst many Muslims. This was due, largely, on account of the failure of other leaders, and how that Bin Laden inspired hope in the revival of Islam, with the assistance of money which he inherited from his father. Zarqawi, on the other hand, aspired to pass-on his abundant experience which he had gained in Afghanistan unto his adherents who were recently released from prison in Jordan. Al Zarqawi, during the struggle in Afghanistan against the Soviet Union, had disagreements with the leadership of Al-Qaeda (Azoulay, 2015: 14-15), and all attempts by Bin Laden to bring-over Zarqawi to the organization and its stated mission were of no avail. During the war in Iraq (1991), friction between Zarqawi and Al-Qaeda only intensified, since Zarqawi categorically determined that authority is given only on the battlefield, rather than in some surreptitious manner. In the years following the American invasion in Afghanistan, but before the invasion in Iraq in 2003, Zarqawi had worked in Iran, Syria, Kurdistan (in northern Iraq) and Iraq, and made contacts with many important jihadist figures who greatly assisted him in his career. A half-year after the American invasion in Iraq, al-Zarqawi started suicide bombings and beheadings against Shi'ites and Sunnis, a thing that enhanced his popularity and encouraged many jihadist fighters to join his ranks. Given Zarqawi's sweeping success, Bin Laden did not wish to be left behind, and after much effort he managed to persuade al-Zarqawi to join his organization, and changed its name to Al-Qaeda in the Land of Two Rivers. Still, in spite of it all, ISIS sees al-Zawahiri as an illegitimate personality who deviated from the path laid out by Bin Laden. According to a senior leader of ISIS, Abu Muhammad al-Adnani al-Sham: "The leaders of Al-Qaeda deviated from the right manhaj, we say this as sadness overwhelms us and bitterness fills our hearts... Verily Al-Qaeda today has ceased to be the base of jihad, rather its leadership has become an axe supporting the destruction of the project of the Islamic State and the coming khilafa (caliphate)... Al-Qaeda now runs after the bandwagon of the majority and calls them as 'the Umma,' and softens in their stance at the expense of the religion, and the taghut (tyrants) of the Ikhwan (Muslim Brotherhood)" (Asharq Al-Awsat, 2014).

In like manner, al-Zawahiri declared: "ISIS is not a branch of the Al-Qaeda group,... [A1-Qaeda] does not have an organizational relationship with it and is not the group responsible for their actions" (ibidem).

The split between al-Qaeda and ISIS is rooted in the differences between the generations belonging to the two organizations. There is a fundamental difference between those who fought with al-Qaeda in Afghanistan during the 80s and during the 90s, and

1 For the different approaches between Al-Qaeda and ISIS: Marinelli, 2015: 16-18. 
those who fought in Iraq and Syria with AQI, and afterwards with ISIS. The big difference is reflected in the fact that the generation of fighters belonging especially to Zarqawi, as of 2011, feel far more committed to jihad, a thing which has led to the great mobilization of fighters into ISIS's ranks. Studies have attributed the cause for such fidelity to the special and extensive relationships developed by Zarqawi with different groups during the Iraq War. The ideological differences between Bin Laden and al-Zarqawi can be summarized by the manner in which the two organizations engage in war on the battlefield. Zarqawi's conceptual view of the world was that the only option available to the Muslim world is the option of jihad, which means that the only way you can purge the Muslim society from infidels (Muslims who strayed from the path of God) is by jihad, whereas Bin Laden and al-Zawahiri believed that Muslims were not the problem at all, but rather, the West was the source of the problem (Zelin, 2014: 1-3, 5-6).

\title{
WHERE ARE WE HEADED?
}

\begin{abstract}
"The U.S. must recognize that its policy of defeating ISIS is insufficient. American national security requires a regional policy to stabilize the Middle East. Syria is a failed state, and policymakers must make plans that assume that disorder in Syria will continue into the future. Like Assad, ISIS has done much to undermine the paradigm that statehood yields security, a condition once reinforced by the international system. The further growth of ISIS is one among many threats that will emerge in as other states in the Middle East become vulnerable. The only way to defeat ISIS, which is necessary for U.S. national security, is to guarantee a ground force that will occupy. secure, and rebuild Syria, and Iraq to a lesser extent. Washington may have little desire to pursue the construction of such ground forces through U.S. partnership. More limited solutions leveraging regional actors, however, are insufficient to shape ground conditions that promote stability and reduce the opportunity for groups like ISIS to remain" (Mcfate, 2015: 7).
\end{abstract}

ISIS's successes on the battlefield, both in Iraq and in Syria, highlight the failure of nation-states in the Middle East, and bring the Middle East into a new era that transforms existing order, and which provides great motivation unto other radical groups to increase their acts of terror in the Middle-East and worldwide. The decentralized but flexible organizational structure that al-Baghdadi implemented, coupled with the weakness of Muslim rulers in their respective countries, were the decisive factors that led to the sweeping success of the organization, while its decentralization and organizational efficiency made it very difficult for the West to deal effectively against them. The international community's lack of efficiency (principally that of the United-States) paved the way for the expansion of the Islamic State, and by all appearances it seems that Jordan is the next target of the organization, which can easily become the catalyst that sets in motion wars all throughout the Middle East (Dekel, Michael, 2014: 3-4). The great popularity enjoyed by the Islamic State during the years 2013-2014 has brought enlightenment to thousands of jihadist youths from around the world who seek to join the organization's ranks. This process, as of today, still leads many Muslim youth into joining ISIS, something that breathes new life into 
the ranks of the organization, leading to the proliferation and augmentation of the organization (Ottaway, 2015: 3, 8-9). As long as the organization's leadership succeed in maintaining its great momentum which it had gained by al-Baghdadi's unilateral declaration announcing the establishment of an Islamic State and his proclaiming of himself to be its official Caliph (Chulov, 2014: 37-39), and as long as it continues to maintain hegemony over the territory it had captured in Iraq and in Syria, the organization will only continue to grow.

The weakness demonstrated by the United States in its struggle against ISIS, and because of the weakness projected by Muslim regimes in the Middle East, especially in Libya and in Yemen, they have all served in strengthening and in giving structural soundness to the Islamic State's formation. In terms of the current situation, over time, only the western-aligned Islamic coalition will be able to strengthen the Islamic State ideology, by pointing out the fact that the Shi' ite world with the secular rulers of Arab countries and the United States have conspired together in order to cripple and stymie the Sunni world in the Middle East. Organizations which lend support to the Islamic State have, in effect, caused the collaboration which led Al-Qaeda in the Arabian Peninsula (AQAP) to conduct acts of terror in Paris in 2015 (see: Zimmerman, 2013), a thing that illustrates the dangers which lurk along the way in the development of the Islamic State. The mutual cooperation which exists between ISIS and the Worldwide Jihad ought to signal an alarm unto western analysts. That is to say, the realization that the Islamic State is getting stronger and is strengthening the Worldwide Jihad needs to be seriously analyzed by the West and its allies. As long as the Islamic State continues to be successful in its struggle in Iraq and in Syria, its legitimacy in the Muslim world will only grow. However, as long as the West is successful in its struggle against the Islamic State, and as long as the West causes weakness to the organization, and when the supporters of the Islamic State will understand that the organization isn't as strong as it is portrayed to be, it will then be possible to downsize the organization to its true and unimposing size (Bunzel, 2015: 36).

As long as the Unites States' struggle against ISIS is prolonged, the chances of succeeding in the struggle against the radical organization will diminish, since public opinion in the United States will also change, and eventually, just as in the past, they'll lose interest and will pressure decision makers to concentrate on other more urgent matters (Conettat, 2014: 1). In all that concerns its fight against ISIS, the United States has entered a new phase which can be compared to the struggle it had before September 11, 2001, concerning which no real solution seems likely in the near future. Even if the United States should succeed in defeating ISIS, just as they had done to AQI before them, the successors of ISIS, as well as other jihadists, would still come along and threaten the United States and her allies in the Middle East. Yet, before the United States and her allies in the Middle East will understand how to deal effectively with ISIS's and other jihadist groups' radical ideology, they still will not be able to completely free themselves from their grip. Years of struggle against extremist groups in the region still lay in store for the United States, although apparently the United States chooses to learn the hard way the well-known saying: "If you do not come to visit the Middle East, it will come and visit you" (Eisenstadt, 2014: 10). 
ISIS's radical ideology, in addition to the extreme violence that it carries out against citizens, such as beheadings, mass executions, etc., do not prevent many Muslims from around the world from longing to join the ranks of the extremist organization, from the many young people to women with their babes, who go to great ends to make themselves members of this organization. The trend that has many Muslims from the West regularly joining the ranks of ISIS underscores a few of the more important points which the West would do well to understand and take into consideration:

- ISIS and the Islamic State concept are the fulfillment of an age-old dream underlying the assumption that by returning to the roots of Islam it provides a solution for many of the problems facing the Muslims throughout the world;

- The hierarchal structure which was installed by Baghdadi in ISIS gives to the organization the flexibility that it so desperately needs in changing conditions of uncertainty on the battlefield;

- ISIS has exceptional organizational skills and the ability to enlist new members into the ranks of the organization, being one of the main reasons for the organization's success and prosperity;

- The tremendous support garnered by the organization, in spite of all the acts of outrage carried out by its members, should set-off alarm bells among decision-makers in the West;

- ISIS's successes on the battlefield in Iraq and Syria are the best propaganda of the organization and are the most important factors which encourage many Muslims, who are vacillating, to try to fulfill the Islamic dream;

- Contrary to the view of many in the West who think that ISIS's goal today is to go to war against the West, today ISIS is mainly concerned with its struggle against the near enemy (Muslims infidels) and completes - in the meantime - the construction of the Islamic State, and only after the termination of these processes will it, without any shadow of a doubt, turn all the power and resources it has against the far enemy, the West;

- In view of the facts mentioned above, only a combination of forces (mainly political) both in the West and in the Islamic world, and only through a joint effort that is, both, consistent and determined, will it be possible to avoid the disaster that is happening already in the Arab world, and which is about to undo all the gains of the West;

- By a joint effort it is necessary to strengthen the legitimacy of the sovereign power in Iraq, and the Peshmerga (Kurdish fighters), and to bolster them with equipment and supplies which they stand in need of while confronting ISIS;

- It is necessary to prevent, by a consistent and joint effort of the entire international community, the infiltration of pro-jihadist fighter into Iraq and Syria;

- The Western allied forces should strive to hit fuel depots, and the principal sources of revenues belonging to ISIS, something that will sorely undermine the current functioning ability of the organization. 


\section{BIBLIOGRAPHY}

Abbas H. (2014), Origin of ISIS; global impact and potential foothold in Pakistan, strategic security initiative, Jinnah Institute, Policy Brief, Washington DC.

Asharq Al-Awsat (2014), Al-Qaeda breaks links with ISIS, Asharq Al-Awsat, 3.02.2014, http://english.aawsat.com/2014/02/article55328465/al-qaeda-breaks-links-with-isis (2.03.2016).

Azoulay R. (2015), Islamic State franchising Tribes, transnational jihadi networks and generational shifts, Clingendael, Netherlands Institute of International Relations, Wassenaar.

Barack E. (2012), Islam is our Gospel and Jihad is our Way, Hassan al Banna, file epistles, Tel Aviv (Hebrew).

Byman D. L. (2015), Comparing Al Qaeda and ISIS: Different goals, different targets, Brookings. Center of Middle East Policy.

Belkeziz A. (2009), The state in contemporary Islamic thought: a historical survey of the major Muslim political thinkers of the modern era Contemporary Arab scholarship in the social sciences, London.

Blumenau B. (2015), ISIS: Understanding the Threat and Its Implications for the West, International History, Graduate Institute, Geneva, No. 6.

Bunzel C. (2015), From Paper State to Caliphate: The Ideology of the Islamic State, Center for Middle East Policy at Brookings Project on U.S. Relations with the Islamic World, Analysis Paper No. 19.

Carmon Y., Joshua Y., Arie A. (2014), The phenomenon of Abu Bakr al-Baghdadi and the Islamic Caliphate state, MEMRI, The Middle East Media Research Institute (Hebrew).

Chulov M. (2014), ISIS: The inside story, "The Guardian", 11.12.2014.

Conettat C. (2014), Something in the Air: "Isolationism”, Defense Spending, and the US Public Mood, International Policy Report, Project on Defense Alternatives, Washington DC.

Cottee S. (2010), Mind Slaughter: The Neutralizations of Jihadi Salafism, "Studies in Conflict \& Terrorism", Vol. 33, No. 4.

Dekel U., Michael K. (2014), ISIS Success in Iraq and Syria: Strategic Ramifications, INSS, Institute for National Security Insight. No. 563.

Eckman J. P. (2014), Is ISIS Leader Abu Bakr al-Baghdadi the New Osama bin-Laden?, Issues In Perspective, Omaha, Nebraska.

Eisenstadt M. (2014), Defeating ISIS, A Strategy for a Resilient Adversary and an Intractable Conflict, Policy Notes, The Washington Institute for Near East Policy, No. 20.

Finer J., Knickmeyer E. (2006), Insurgent Leader Al-Zarqawi Killed in Iraq, Washington Post Foreign Service.

Fishman B. (2008), Disfunction and Decline: Lessons Learned From Inside Al-Qa'ida in Iraq, Combating Terrorism Center, US Military Academy, West Point, NY.

Fishman B. (2014), The Islamic State: A Persistent Threat, Counterterrorism research, fellow international security program, at the new America foundation.

Hashim A. S. (2014), The Islamic State: From al-Qaeda Affiliate to Caliphate, "Middle East Policy". Vol. XXI, No. 4.

Ibrahim R. (2014), New Islamic Caliphate Declares Jihad on... Muslims, "Middle East Forum", MEF Research and Writing.

ISIS: Portrait of a Jihadi Terrorist Organization (2014), The Meir Amit Intelligence and Terrorism Information Center, Israeli Inelegance Heritage and Commemoration Center, Herzliya. 
Kahati Y. (2006), Abu Musab al-Zarqawi: his biography, world-view and contribution to the ongoing jihad in Iraq, Intelligence and Terrorism Information Center at the Center for Special Studies (C.S.S.).

Katzman K. (2009), Iraq: Politics, Elections, and Benchmarks, Congressional Research Service, CRS Report for Congress, 7-5700.

Knapp M. G. (2002), Distortion of Islam by Muslim extremists, U.S. Army Department of Defense, Military Intelligence.

Marinelli J. P. B. (2015), Beyond the Black Flag: Modernism, Ideology, and the Rise of ISIS, Honor's Theses, Bucknell Digital Commons, Bucknell University, Paper 305.

Mcfate J. L. (2015), The ISIS defense in Iraq and Syria: countering an adaptive enemy, "Middle East Security Report", No. 27.

Nance M. W. (2015), The metamorphosis from AQI to the Islamic state of Iraq (2006-2011), The Counter Terrorist Magazine Excerpted from The Terrorists of Iraq by Malcolm Nance (Taylor and Francis, 2014), Miami.

Napoleoni L. (2015), The Islamist Phoenix: The Islamic State and the Redrawing of the Middle East, Reviewed by José de Arimateia da Cruz, Within US Army War College, "Quarterly Parameters, Spring 2015", Vol. 45, No. 1.

Ottaway M. (2015), ISIS: Many Faces, Different Battles, Wilson Center, Middle East Program, Occasional Paper Series.

Perthes V. (2014), Islamic State (IS), Qantara.de, A totalitarian, expansive and hegemonic project. 6.10.2014, Stuttgart, http://en.qantara.de/content/islamic-state-is-a-totalitarian-expansiveand-hegemonic-project (2.03.2016).

Raphaeli N. (2005), The Sheikh of the Slaughterers, Abu Mus'ab Al-Zarqawi and the Al-Qa'ida connection, The Middle East Media Research Institute (MEMRI), Washington DC.

Roggio B. (2010), US and Iraqi forces kill Al Masri and Baghdadi, al Qaeda in Iraq's top two leaders, the long war journal, A project of the foundation for defense of democracies, Medford, NJ.

Roy O. (2008), Al Qaeda in the West as a Youth Movement: The Power of a Narrative, Central and Eastern European Online Library, CEPS Policy Briefs, Issue 1-12.

Sirriyeh E. (2000), Rashid Rida's Autobiography of the Syrian Years, 1865-1897, "Arabic and Middle Eastern Literatures", Vol. 3, No. 2.

Sivan E. (1989), Sunni Radicalism in the Middle East and the Iranian Revolution, "International Journal of Middle East Studies", Vol. 21, No. 1.

The Islamic State. Special report (2015), The Clarion Project, Washington DC.

Wagemakers J. (2014), A Terrorist Organization that Never Was: The Jordanian "Bay'at al-Imam" Group, "Middle East Journal", Vol. 68, No. 1.

Wood G. (2014), The secrets of ISIS, a revealing history of the new caliphate, "The New Republic". 15.09.2014.

Zelin A. Y. (2014), The War between ISIS and al-Qaeda for Supremacy of the Global Jihadist Movement, Research NOTE 20, The Washington Institute for Near East Policy, Washington.

Zimmerman K. L. (2013), AQAP's Role in the al Qaeda Network, Statement before the House Committee on Homeland Security Subcommittee on Counterterrorism and Intelligence on "Understanding the Threat to the Homeland from AQAP", American Enterprise Institute, for Public Policy Research, Washington DC.

Zirvi K. (2008), Official gazette of the Ahnadiyya movement in Islam, "The Ahmadiyya Gazette, An informational, literary, educational, and training magazine of Ahmadiyya Muslim Community", USA, AMI publication. 


\begin{abstract}
The main purpose of this article is to examine the causes which led to the establishment of ISIS. In addition, this text aims to get to the root of ISIS's ideology and analyze step-by-step the driving factors and circumstances that led to the emergence of the Islamic State. Moreover, it purports to examine the dichotomous relationship between ISIS and al-Qaeda, and finally examine where the west and the Muslim world are headed.
\end{abstract}

Key words: ISIS, al-Qaeda, Islam, the Islamic State, Bin Laden, al-Zarqawi, al-Baghdadi, al-Zawahiri.

\title{
ISIS: PRZESZLOŚĆ, TERAŹNIEJSZOŚĆ I PRZYSZLOŚĆ
}

\section{STRESZCZENIE}

Głównym celem artykułu jest analiza przyczyn, które doprowadziły do powstania ISIS. Dodatkowo zwrócono uwagę na podstawę ideologiczną ISIS, która także przyczyniła się do powstania tzw. "Państwa Islamskiego". Ponadto ukazano dychotomię pomiędzy ISIS a al-Kaidą, by wreszcie poddać refleksji w jakim kierunku zmierza Zachód i świat muzułmański.

Slowa kluczowe: ISIS, tzw. Państwo Islamskie, al-Kaida, Bin Laden, al-Zarqawi, al-Baghdadi, al-Zawahiri 